\title{
Towards the inculturation of marriage rituals in the National Baptist Convention of Zimbabwe
}

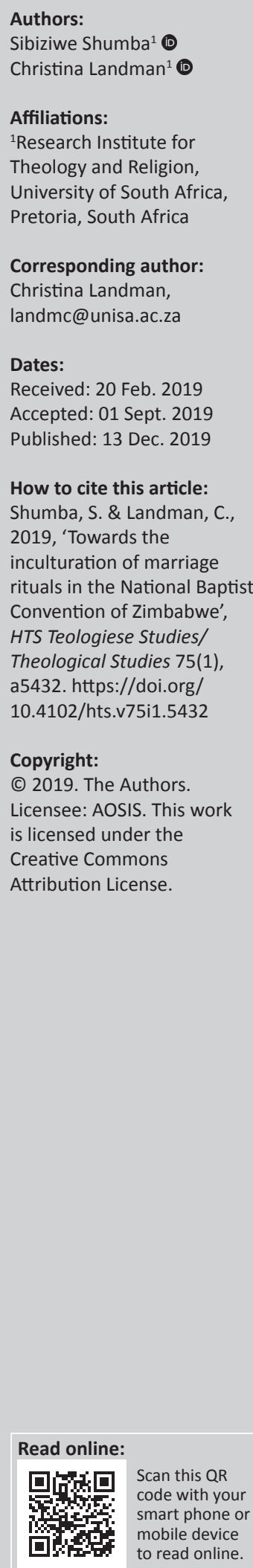

In this article, we seek to give a missiological critique of the inculturation of marriage rituals in the National Baptist Convention (NBC) of Zimbabwe. We examine and explore the inculturation that could help expedite greater engagement between the NBC of Zimbabwe and the Shona and Ndebele cultures in Midlands and Matabeleland regions. The challenges facing the inculturation of marriage rituals are examined. We use missiological research methodologies that include the seven-point praxis matrix propounded by Kritzinger. The praxis matrix is used as a grid of missiological questions in qualitative paradigms. A case study design and sample of fifteen research respondents from six of the thirteen denominations are used. The sample includes the National Executive members, pastors, elders, deacons, church committee members and lay member. Interviews and observations are the instruments. The findings reveal that Convention members regard inculturation of marriage rituals important. They inculturated payment of bride price, ululating, dancing, and marrying someone whose background is known since they are biblical. Polygamy, divination and ancestor veneration is rejected. Kusungira ritual and conducting marriage rituals in November is controversial. Inculturation is hindered by fear of syncretism, clash of doctrines, expensive and oppressive and many ethnic groups in the Convention. It is recommended that the Convention encourages payment of bride price and carefully handles controversies surrounding marriage rituals. The preaching and teaching against views that perpetuate patriarchy subordination of women by men men in the society and the fusion of the church and traditional wedding ceremonies should be encouraged.

Keywords: National Baptist Convention of Zimbabwe; inculturation of marriage rituals; praxis matrix; Shona and Ndebele cultures; bride price; monogamy/polygamy; convention.

\section{Introduction \\ Literary background}

A variety of books, theses and articles have been written about inculturation in African churches, of which only a few will be mentioned here, with an emphasis on works on Zimbabwe.

Magesa's book, entitled The Anatomy of Inculturation: Transforming the Church in Africa (2004), focuses on inculturation in both the Catholic Church and the African Independent Pentecostal Church of Africa (AIPCA). Magesa (2004:10) showed that Christian doctrines are mixed with 'useful' African traditional cultural values and a modern way of life to make Christianity a religion that is acceptable to all. Anthony (2012) and Kurgat (2009) have also written on the importance of inculturation in Africa.

In Zimbabwe, most of the works on inculturation were written either by Roman Catholic scholars or by scholars focusing on the Roman Catholic Church. For instance, Gundani's article (2000) entitled 'Christology in the inculturated Shona Burial' discusses inculturation in the Shona Catholic Church, with the objective of investigating the place given to Christ. In the research, Gundani (2000:91) discovered that Christ is exhibited as 'the life and resurrection' and 'the way to the Father'. Christ is shown as the liberator who leads the departed out of the world of impermanence to everlasting life. Christ is the ultimate Victor [Christus Victor].

Amadi's article (2002), entitled 'Inculturating the Eucharist in Zimbabwe', explores possible ways of making the Eucharist celebration meaningful to the Catholics in Mutare. Some of these ways included symbolic gestures, local languages, proverbs, local staple food and invocation of ancestors. 
Mwandayi's book (2011), entitled Death and after-life rituals in the eyes of the Shona: Dialogue with Shona customs in the quest for authentic inculturation, examines the burial customs and rituals amongst the Shona. He observes a definite pattern comparable to the Judeo-Christian practices. Mwandayi (2011:1) contends that these practices amongst the Shona are a preparation for the Gospel of Christ.

Moving towards marriage rites, Shoko (2009) wrote an article on 'Komba girls' initiation rites and inculturation among the Varemba of Zimbabwe'. According to Shoko (2009):

The Komba rite is intended to move a mature girl (mhandara) from the state of girlhood to that of womanhood. It is also meant to initiate Vashenji (uncircumcised non-Varemba) women who marry Varemba men into their female traditions and customs ... (p. 1)

Still on the Shona-Karanga ethnic group in Zimbabwe, the Varemba boys (majaha) are circumcised during the murundu initiation rite. In this ritual, elderly men of the Varemba group are appointed to lead such rites. In the abstract, Shoko (2009) points out that whilst Christianity despised this rite as 'paganism' and not acceptable to its faith, the Varemba Christians practise it in good faith. As such, the article explores the relationship of the Komba ritual with some Catholic Church sacraments. By so doing, the article even endeavours to address the problem of whether the rite can be accommodated into Catholic sacraments like baptism, confirmation and matrimony and argues for the inculturation of the Komba rite.

There is a scarcity of inculturation articles with regard to marriage rites, and no articles have been written on this phenomenon in the NBC of Zimbabwe. In the light of this, an academic article was undertaken in which we as academics focused on inculturation in relation to marriage rituals in the NBC of Zimbabwe, the results which are reported in this article.

\section{Problem statement}

Inculturation from a Christian theological perspective is perceived as a process in which the faith embodied in one culture encounters another culture (Magesa 2004:5). Bronislaw Malinowski in Niebuhr (2001:32) defines culture as the 'artificial secondary environment' which 'man' superimposes on the natural. In the case of the NBC of Zimbabwe, it is the Christian faith message encountering African traditional culture in the form of the Shona and Ndebele cultures, becoming part of a new culture. The Christian culture in this case inculturates the Shona and Ndebele marriage rituals. Thus, the following research questions arise: 'how does inculturation work between Christian and traditional Shona and Ndebele cultures?', 'Is there a conflict inherent to this inculturation?', 'What form does this conflict take?' and 'Does it lead to deculturation?' This kind of encounter is likely to bring a conflict of cultures. It brings deculturation as well.
Two cultures, namely, one based on Christian faith and practice and the other based on Shona and Ndebele religious and traditional practices, can be harmonised in conducting marriage rituals in the Convention. In many church formations, African traditional practices and the Christian faith are mutually exclusive. This divides personal allegiance of church members between culture and faith. It divides members of the same families into opposing camps, as it is an inherent problem to individual peace and sanity, and it is a problem for social harmony and cohesion.

It is clear that this article exposes a problem that needs to be investigated. In brief, the research problem that will be investigated is as follows: what are the challenges facing the inculturation of marriage practices, specifically in the NBC of Zimbabwe, with special reference to the Shona and Ndebele cultures in Midlands and Matabeleland?

\section{Aims and objectives of the study}

This research article focuses on the inculturation of marriage rituals, interrogating and exploring the models of inculturation that would help facilitate greater engagement between the NBC of Zimbabwe and the Shona and Ndebele cultures in the Midlands and Matabeleland regions. The purpose of the article is to analyse the NBC of Zimbabwe, concentrating on inculturation in marriage rituals by making an inquiry into the following:

- the religious and traditional orientations of agents and/ or leaders who work towards inculturation and their position of responsibility vis-à-vis the rest of the NBC of Zimbabwe and their views on inculturation (Agency).

- the factors that influence the agents and the society and/ or church members who are affected by this inculturation, the context of the members of the NBC of Zimbabwe as Shonas and Ndebeles and the perceptions of respondents regarding inculturation in the Convention in their context (Contextual understanding).

- the marriage practices that were or are in the churches barriers to the practice of such aspects in the Convention and the kind of inculturation that could facilitate greater engagement between the NBC of Zimbabwe and the Shona and the Ndebele cultures (Ecclesial scrutiny).

- the leaders' and the members' interpretation of the Bible vis-à-vis marriage practices and the appropriate spirituality for inculturating marriage practices (Biblical tradition).

- the actions taken to inculturate marriage practices and the causes of the blending of these practices in this Convention (Discernment for action).

- the reflections from leaders and members on the impact of the inculturation of marriage practices, aspects of Shona and Ndebele cultures that have been fused in the NBC of Zimbabwe and the possible benefits of these aspects for the Convention members (Reflexivity).

- finally, the type of spirituality practised by the leaders and/or members that underscores the inculturation of the marriage rituals (Spirituality). 


\section{Research methods and design}

\section{Study design}

In this article, we used a case study design focusing on the NBC of Zimbabwe. This strongly aids in determining the kind of inculturation that would facilitate greater engagement of inculturation between the NBC of Zimbabwe and the Shona and Ndebele cultures. A qualitative research design was used.

Qualitative research is based on an interpretive paradigm. Interpretive approaches to research have the purpose of understanding the world of human experience (Cohen \& Manion 1994:36). This suggests that reality is socially constructed as propounded by Mertens (2005:12). Creswell (2010:38) asserts that an interpretive researcher relies on the participants' views of the situation under study and takes cognisance of the impact of their own experiences on the research. Creswell (2010:38) further says that the interpretive researcher mostly relies on qualitative data collection methods and analysis, or a combination of qualitative and quantitative methods. In this article, we used qualitative methods to adequately describe or interpret a situation in relation to the inculturation of marriage rituals in the NBC of Zimbabwe in the Midlands and Matabeleland regions. Creswell \& Plano Clark's (2011:13) mixed method research was not used although it has advantages.

\section{Research methods}

In this article, we used the seven-point pastoral cycle as propounded by Kritzinger (2010) as the framework for the missiological questions. Figure 1 presents a diagram of the seven-dimension pastoral cycle.

This 'praxis matrix' developed by Kritzinger (cited in Banda 2010:128) is what we have applied to the research question. The main aspects of the matrix are (1) Agency, (2) Contextual understanding, (3) Ecclesial scrutiny, (4) Theological interpretation, (5) Strategic planning,

(6) Reflexivity and (7) Spirituality.

Kritzinger and others have applied it as a methodological framework, and in this article we use it as the framework for the missiological questions. MTHMS 15 (2010) has a very brief and succinct explanation of the Praxis Cycle whilst Baron et al (2017) has a current approach to the cycle which we applied in the article.

\section{Setting}

This article on the missiological critique of marriage rituals was concerned only with the churches of the NBC of Zimbabwe, which are located in the Matabeleland ${ }^{1}$ and Midlands regions. By concentrating on a small section, we avoid hasty conclusions and unproductive generalisations. Figure 2 presents the political map of Zimbabwe showing

1.Matabeleland is regarded as Matabeleland North and South on the political map in Figure 2 .

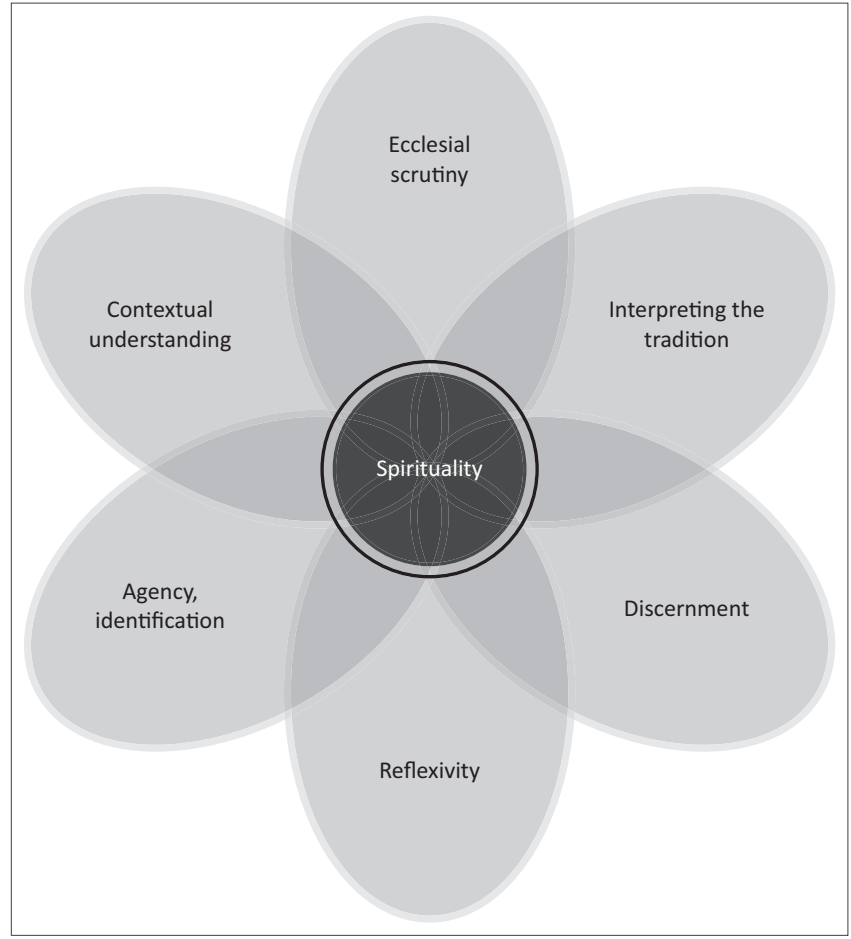

Source: Banda, Z., 2010, 'African renaissance and missiology: A perspective from mission praxis', Unpublished DTh. thesis, Unisa

FIGURE 1: Kritzinger's seven-point 'praxis matrix'.

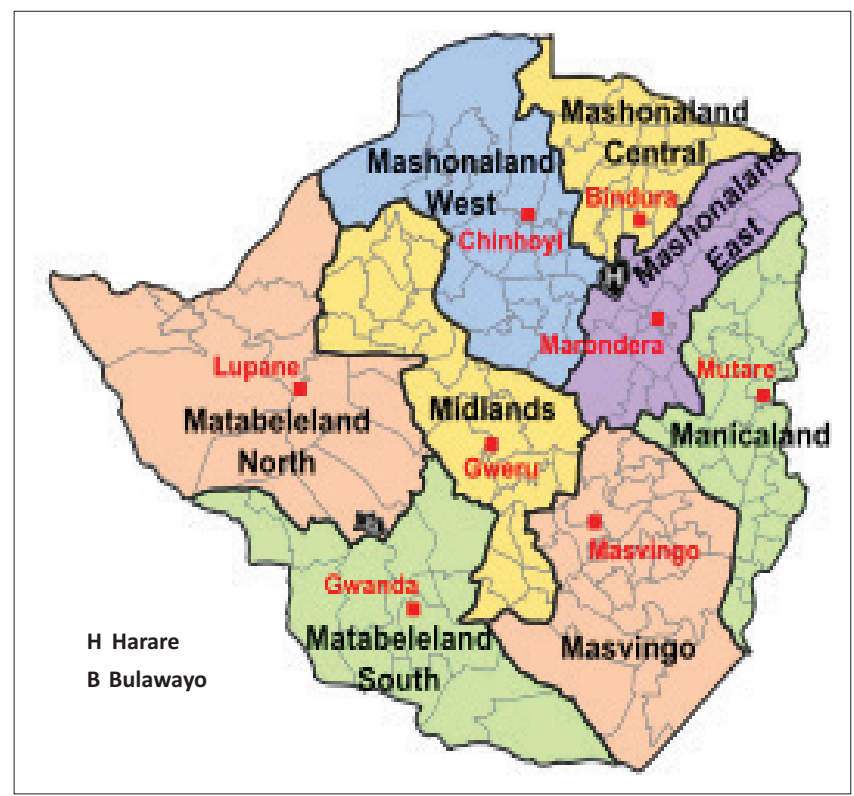

Source: www.google.com/search

FIGURE 2: Political Map of Zimbabwe showing Matabeleland North and South as well as the Midlands regions from where the research population and sample were taken.

Midlands and Matabeleland regions from where the population and sample of the study were drawn.

In this article, we focused mainly on the Shona and Ndebele cultures, leaving out the Kalanga, Venda Shangaan, Sotho or Chewa cultures. We have selected the Shona and Ndebele cultures because the Shona and Ndebele people form a greater percentage compared to that of other ethnic groups. ${ }^{2}$

2.NewZimbabwe.com says, 'according to government statistics, the Shona ethnic group made $82 \%$ of the population, Ndebele $14 \%$, Whites and Asians less than $1 \%$ 


\section{Sample population and sampling strategy}

The sample population comprised all congregates in the 13 churches of the NBC of Zimbabwe in Matabeleland and Midlands regions. This covered Gwanda, Bulawayo, Victoria Falls and Gweru. All pastors, elders, deacons, church committee members, the National Executive Committee members and the ordinary congregants of the Convention were considered.

\section{Sample}

We chose a research sample of 15 interviewees from 6 of the 13 denominations of the NBC of Zimbabwe in Midlands and Matabeleland regions.

\section{The coding system used in the study}

This presentation is punctuated with quoted statements from the participants in order to authenticate the findings. In an effort to present the quotations, we used codes for referencing purposes. The codes are presented in Tables 1 and 2 .

Table 1 shows that all the six churches studied and the interviewees in the article were given pseudonyms A, B, C, D, E and F, respectively. Each participant from a church was numbered in ascending order per church and position for ease of identification. The numerals show the position of that interviewees in the church. For instance, 1 is for pastors, 2 for elders, 3 for deacons, 4 for church committee members and 5 was for lay members interviewed. The pastors were given pseudonyms: pastor $\mathrm{A} 1, \mathrm{~B} 1$ and $\mathrm{C} 1$, etc. Elders were given pseudonyms like B2, C2 and D2. The deacons were coded as D3 and E3. Church committee members were coded as A4 and F4. Lay members were coded as B5 and C5. From the data in the table, this shows that pastor A1 comes from church $\mathrm{A}$ and is number 1 in the church, whilst elder B2 comes from church B and is number 2 in that church. In this case, the alphabet would be identifying interviewee with the name of his or her church and the position he or she occupied. These were then transcribed for data presentation and analysis.

Table 2 shows the pseudonyms given to three National Executive members. These are NEM1, NEM2 and NEM3. In this case, NEM1 represents National Executive Member number 1, NEM2 represents National Executive Member number 2, whilst NEM3 represents National Executive Member number 3.

All the interviews for code systems (i) and (ii) were voicerecorded in a numerical and ascending order from the first to the last one with the interview date (e.g. Interview 1, 14 November 2016). These were then transcribed for data presentation and analysis. Each participant from a church was numbered in ascending order per church and position for ease of identification, whilst for National Executive members this was based on positions only. As such the interviewees would be labelled, Elder D2 (Interview 1, and other ethnic and racial groups $3 \%$.
TABLE 1: Code system (i) - Coding used in the study of churches, pastors, elders, deacons, church committee members and lay members.

\begin{tabular}{|c|c|c|c|c|c|}
\hline $\begin{array}{l}\text { Name of the } \\
\text { church }\end{array}$ & Pastor & Elder & Deacon & $\begin{array}{l}\text { Church committee } \\
\text { member }\end{array}$ & Lay person \\
\hline A & $\mathrm{A} 1$ & $\ldots+\ldots \ldots \ldots . .$. & .................. & A4 & .................. \\
\hline B & B1 & B2 & ……............ & ……............ & B5 \\
\hline C & $\mathrm{C} 1$ & C2 & ……........... & ………....... & $\mathrm{C} 5$ \\
\hline D & $\ldots \ldots \ldots \ldots \ldots . .$. & D2 & D3 & ……........... & $\ldots+\ldots \ldots \ldots . .$. \\
\hline E & ……............ & $\ldots$ & E3 & ……........... & ……............ \\
\hline $\mathrm{F}$ & ...................... & ……….......... & $\ldots \ldots \ldots \ldots \ldots$ & F4 & ................ \\
\hline
\end{tabular}
position.

TABLE 2: Code system (ii) - Coding system used in the study of three National Executive members.

\begin{tabular}{ll}
\hline Description & Code \\
\hline National executive number 1 & NEM1 \\
National executive number 2 & NEM2 \\
National executive number 3 & NEM3 \\
\hline
\end{tabular}

14 November 2016), or Pastor B1 (Interview 4, 17 November 2016). Only 15 people were interviewed.

Those aged between 20 and 79 years were considered for the study. Gender was considered as culture amongst black Africans in Southern Africa is strongly 'arranged' according to gender roles and hierarchies between different genders and age groups.

\section{Data collection tools}

These are the research instruments which are the tools that help researchers to achieve their goals (Leedy1993:25). Observations $^{3}$ and interviews were employed for data collection. An interview schedule was designed. We alternated between participant and non-participant observations. An observation sheet was used.

We used a sequential design. Firstly, qualitative data were collected through formal and informal interviews ${ }^{4}$ from 15 interviewees. We designed two interview guides for Shona and Ndebele cultures. The use of interviews had advantages because they allow researchers to freely use probes (Johnson \& Christensen 2008:203).

Through interviews we were able to access the thoughts and the value attached to them. As mentioned before, the interviewees were drawn from those in leadership positions, such as pastors, elders, deacons, church committee members and some members of the National Executive Committee. Members of the lay people were also interviewed.

Face-to-face interviews had the advantage in that as interviewers we could control the context and the environment in which the interview was taking place (Phellas, Bloch \& Seale 2011:183). However, the interviewees also co-determined that environment to some extent.

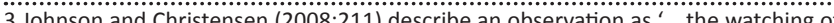
behaviour patterns of people in cettain situations to obtain the phenomenon of interest ....

4.Johnson and Christensen (2008:203) define an interview as a data collection method in which an interviewer asks a question to an interviewee. 
We ensured that the interview took place in an appropriate setting, which was conducive to accurate responses. We also ensured that all the questions have been asked and answered in the correct order as expected. The questions were based on the nature, causes, benefits and constraints of inculturation in the NBC of Zimbabwe.

Face-to-face interviews had the distinct advantage of enabling us to establish a good rapport with the potential participants and therefore gain their cooperation (Leedy \& Omrod 2010:148). Thus, using interviews in this research study yielded the highest response rates. This means that the percentage of people who agreed to participate on the evaluation of inculturation was very high. However, the time and the costs involved were a deterrent factor if the needed interviewees resided in different provinces like the Midlands and Matabeleland regions.

Lastly, integration of qualitative and observations data was done. ${ }^{5}$

\section{Data collection procedures}

We sought permission from the National Executive Office of the Convention, the University of South Africa (UNISA) and other responsible authorities to collect data from the pastors, elders, deacons, committee members and lay members. We received an ethical clearance letter from UNISA.

\section{Data analysis}

We analysed data through thick thematic narrative descriptions. The MS Word was used to transcribe the qualitative data obtained.

\section{Summary of results per objectives of the study}

Our purpose in this article was to examine and explore the kind of inculturation that would help facilitate greater engagement of inculturation of the marriage rituals between the NBC of Zimbabwe and the Shona and Ndebele cultures in the Midlands and Matabeleland regions. The main purpose was basically to critique the NBC of Zimbabwe, concentrating on inculturation of marriage rituals. In this section, a summary of the results is presented according to the research aim and objectives.

\section{Existence of inculturation of Shona and Ndebele cultural marriage rituals in the National Baptist Convention of Zimbabwe in the previous years}

In line with objective 1 on agency, we observed that the NBC of Zimbabwe leaders like National Executive members, pastors, elders, deacons and church committee members worked towards the inculturation of marriage rituals in the Convention. The majority of these agents acknowledged the fact that inculturation of marriage rituals had been in existence in the Convention since the time they became members. Shona and Ndebele cultural practices, which were biblical in nature, were observed in the running of marriage rituals. For instance, Pastor B1 from Matabeleland in Bulawayo city (Interview 4, 17 November 2016) confirmed this, saying:

'Yes, there was use of Ndebele cultural aspects in this church when I became a member in 1990, because every young man who wanted to wed in church was supposed to have paid bride price (amalobolo) to the parents of the woman. Failure to do that means the wedding would not be conducted in the church.'

The above response shows that the payment of bride price has been practised in the church as far back as from 1990 up to now. Pastor A1 (Interview 7, 08 December 2016) from Midlands in Gweru town agreed, saying:

'When I became a member of the NBC of Zimbabwe, the use of Shona cultural aspects in marriage rituals was there. I remember that in 1992 my brother had to pay eight heads of cattle as part of the bride price for him to wed in the church. The church leaders were even in support of such a move saying this was part of our Shona culture, which should be followed in the church.'

The above two responses were supported by Deacon E3 (Interview 15, 31 January 2017), who said:

'The Shona cultural ritual of sending a woman to her home area during her first pregnancy for a kusungira ritual has been in existence in the NBC of Zimbabwe since 1991. The church leaders were in support of that because they were of the idea that my wife would get guidance and counselling on how to handle the newly born baby from her parents and relatives since that was her first pregnancy. The church leaders never cautioned me in line with that.'

From the above responses, we concluded that aspects of Shona and Ndebele marriage cultural practices in the NBC of Zimbabwe date back to as far as 1990 . However, one of the interviewees pointed out that she had not observed such Shona and Ndebele cultural aspects in the NBC of Zimbabwe. This may be a result of the fact that she wanted to protect the integrity of the Convention trying to keep it pure from syncretism or she had not been exposed to such Shona and Ndebele cultural aspects.

\section{Role of the inculturation of marriage rituals in the National Baptist Convention of Zimbabwe}

In line with objective 2 on contextual understanding, we noted from most of the interview responses that the agents thought that inculturation played an important role in the NBC of Zimbabwe in encouraging the upholding of marriage of cultural rituals. This was confirmed by a number of interviewees from Gweru in Midlands and Bulawayo in Matabeleland who pointed out that the Shona and Ndebele cultures ensure the payment of bride price ([roora] in Shona language or [amalobolo] in Ndebele language) in line with marriage rituals. Most of the interview results we got in December 2017 supported the above view. For instance, 
Pastor A1 (Interview 7, 08 December 2016) from Gweru in Midlands said:

'The Shona culture can be seen as a model of contextualization. It can be perceived as a pattern in which the character of contemporary Christianity can manifest itself. Together with this, the Shona culture can be viewed as an attempt to translate the Christian faith into a specific culture, the culture of the African church.'

What was asserted by Pastor A1 (Interview 7, 08 December 2016) was supported by a Ndebele church committee member A4 (Interview 8, 08 December 2016), who said:

\begin{abstract}
'The Church in the NBC of Zimbabwe should be the Church, which affords the Ndebele people the means of worshipping God as Ndebeles. This is a way, which is compatible with their own spiritual character, of singing to the glory of God in their own way. As Ndebele people we have our own way of conducting marriage rituals which greatly appeals to us. For instance, we dance, clap hands and ululate during the conduct of a marriage ceremony. We even pay lobola according to the demands of our culture.'
\end{abstract}

Pastor B1 from Bulawayo supported this, saying that the payment of bride price is strongly encouraged by Shona and Ndebele cultures in the NBC of Zimbabwe. According to Pastor B1 (Interview 4, 17 December 2017):

'In the NBC of Zimbabwe, the bride and groom will not be married in the church if they have not paid part of or the whole bride price demanded by the parents or guardian of the bride. In this case, an intermediary plays a paramount role of ensuring that this has happened. The intermediary (Usodombo/umkhongi) helps in uniting the two families who are to be married. All this is in line with Matthew 18 verses 15-17.'

Church committee member F4 (Interview 14, 23 January 2017) from Bulawayo town in the Matabeleland region concurred with the above saying:

'Payment of Amalobolo in the NBC of Zimbabwe is greatly valued as part of our Ndebele marriage cultural practice. This is an appreciation to the parents for keeping the girl. For us church members this is biblical. For instance, when Rebecca was going to marry Isaac, some gifts were given. In the NBC of Zimbabwe, we will be thanking the family of the bride-to-be.'

The majority of interview and observation results revealed that there was a controversy over the time to pay lobola and the conduct of certain marriage rituals. They showed that people did not agree on the proper time. For instance, after one couple at Church D wedded on 13 November 2016 a controversy arose amongst interviewees from various churches in Matabeleland region.

It is worth noting that when the above couple wedded we observed that many debates arose amongst the NBC of Zimbabwe congregation members at Church D in Gwanda town, which is in the Matabeleland region. For instance, on 14 November 2016, Elder D2 at Church D (Interview 1, 14 November 2016) raised a question:
'Why did the couple wed in the sacred month of November yet in Shona and Ndebele cultures it is a taboo to conduct wedding ceremonies in this month? This is not commendable at all. What they have done is not acceptable in both Shona and Ndebele cultures. The two should have done it in another month since November is a sanctified month when no weddings are to be conducted. November is a consecrated month when people begin preparing for the all-important agricultural season.'

Elder D2 was strongly opposed to the idea of conducting marriage rituals in November because she strongly believed in the traditional cultures of the Shona and Ndebele people. She therefore believed that conducting rituals in November was not acceptable as it is a consecrated month when no marriage rituals can be held. Instead, during this time people should start to prepare for the all-important agricultural season.

Another controversy was in line with the conduct of the kusungira ritual where a woman who had her first pregnancy had to be taken to her family relatives for guidance and counselling on how to handle the newly born baby. The Ndebele people pointed out that they held the ritual although under a different name. Some Shona and Ndebele members strongly supported the idea, whilst others were against it as they thought that such roles can also be played by some elderly women from the NBC of Zimbabwe.

Together with this, the interview and observation results showed that inculturation of marriage rituals in the NBC of Zimbabwe had the role of encouraging loyalty and trustworthiness between the couples. This was supported by interview results we got from Pastor C1 on 15 January 2017 at Church C, who said that Shona culture legitimises marriage as the partners seek permission and approval from their parents and family to marry. According to Pastor C1 (Interview 9, 15 January 2017):

'In our church, we encourage that the man and woman who want to be married in this church should first seek permission and approval from the parents or guardians as a basis for good marriage. The parents or guardians are the ones who give us the green light to marry the two.'

From this, we concluded that Shona culture had a role of being a basis for good marriages in the NBC of Zimbabwe.

From most of our observation results about the conduct of a wedding ceremony at Church D in November 2016, in the Midlands region, it was revealed that the Ndebele culture was a basis for strong marriages. For instance, we observed that when the church wedding ceremony was held, the bride and the groom were asked if they were serious about getting married. They even gave marriage vows. The marriage officer asked the bride and the groom questions on whether they were serious about getting into a holy matrimony. The marriage officer asked such a question to the couple in fulfilment of the government requirement whether they were Ndebele or not, to which the two answered accordingly. 
More so, from most of the Shona interview results, we established that guidance and counselling done by the aunts and uncles complemented that of pastors, elders, deacons and the marriage officers within the NBC of Zimbabwe. This was also supported by one of the Shona elders, C2 (Interview 10, 15 January 2017) at Church C, who said:

'When a couple has failed to solve a marital problem, they would seek advice from their aunts and uncles. The NBC of Zimbabwe pastors and elders strongly encouraged couples to come for guidance and counselling when they have marital problems.'

Thus, we can say that pastors, elders and deacons played guidance and counselling roles of aunts and uncles to the married couple. Above all, the church facilitates dialogue between families, and it would intervene where there is a misunderstanding.

The views of the Shona and Ndebele respondents on guidance and counselling are supported by Gombe (2000:61), who points out that during the courtship process the aunts had a paramount role to play in guidance and counselling in traditional Shona society. The aunts guided and counselled both the boy and the girl. The girl was strongly encouraged to maintain good moral behaviour, especially in keeping her virginity. Gombe (2000:61) also noted that in Shona courtship rituals elderly women [chembere] also had a significant role. For example, when a mature girl was taken for marriage they would strongly teach her how to be a good homemaker. Even the uncles played an important role of teaching the mature boy how to be a good husband.

Thus, the Shona culture also played a significant role in guidance and counselling in the NBC of Zimbabwe like what was pointed out by Gombe (2000).

Nyathi (2001:97) also points out that there is guidance and counselling of girls in Ndebele culture. The girl would receive schooling on various issues, including how to become a good wife, how to care for children, tolerable behaviour towards men, sex education and the regulation of one's sexual needs (Nyathi 2001:97). Bozongwana (2000) says:

Lessons begin immediately on how to be a good house wife. Care of children, behavior towards men, use of sex and cookery are some of the things taught to the girl by the oldest woman of the home ... (p. 21)

Therefore, we concluded that the inculturation of marriage rituals played significant roles in the NBC of Zimbabwe.

\section{Marriage practices adopted in the National Baptist Convention of Zimbabwe}

In line with objective 3on the dimension of ecclesial scrutiny, we found that there are or were a number of marriage practices that are or were in the NBC of Zimbabwe churches. In this case, the ecclesial authorities like National
Executive members, pastors, elders, deacons and church committee members determined which Shona and Ndebele cultural practices could be adopted in the Convention following a congregational governance.

These practices included payment of lobola, ukucola, ululation, dancing, clapping of hands in kusungira ritual. ${ }^{6}$

\section{Kind of inculturation that can expedite the inculturation of marriage rituals in the National Baptist Convention of Zimbabwe}

From most of the interviews and observation results, we noted that the kind of inculturation to expedite greater commitment to inculturation between the NBC of Zimbabwe and the Shona and Ndebele cultures was that of encouraging payment of the bride price. All this was confirmed by Gombe (2000), Thorpe (1996) and Andifasi (1970:28) cited in Mangena and Ndlovu (2013:473). In this case, no one was allowed to conduct a wedding ceremony in the NBC of Zimbabwe before one paid part of or the whole bride price as demanded by the in-laws.

Payment was an exhibition of love, which exhibited great commitment of the bride and groom towards marriage.

We even established that the kind of inculturation could ensure that the traditional ritual of paying the bride price could still be conducted within the NBC of Zimbabwe because members thought it was a noble idea. This is in line with the findings of Mangena and Ndlovu (2013:475) that in traditional Ndebele marriage, before the children were born, the girl's father paid more than the boy's father did in the establishment of the new family.

For example, the girl's father gave his daughter a beast to take to her new home. The beast was a sign to the groom's family that the bride was serious with marriage. This beast became the foundation of the home as it multiplied. It also protected the dignity of her and her family throughout the marriage. The type of inculturation had to preach and teach on the advantages of paying lobola in line with the NBC of Zimbabwe marriage rituals. We detected that lobola is a decisive stabilising factor in Shona and Ndebele traditional marriage rituals and a guarantee of indissolubility. ${ }^{7}$ Andifasi (1970:28) cited in Mangena and Ndlovu (2013:473) also said that roora/lobola is '... an outward manifestation of the young man's love for his fiancé and is a safeguard against groundless divorce ...'.

Therefore, the attachment of a value to the woman was a way of according a status, which is commendable even in the NBC of Zimbabwe marriage rituals.

6.Kusungira ritual is a practice where a newly married woman who becomes pregnant for the first time is taken to her parents to live with them from 7-8 months till she gave birth. This was done so that she could be monitored, guided and counselled how to handle the newborn baby by her relatives.

7. Hatendi (1973:144) supports the above idea saying, 'bride price is a significant gift, an acknowledgement of a priceless debt which the bride groom's family group owes an acknowledgement of a priceless debt which the bride groom's family group owes
to the bride's family group .... It legitimizes the children born of the socially accepted union within the father's lineage ...' 
Along with this, we established that the kind of inculturation had to ensure that the groom and relatives appreciated the parents or guardians for bringing up the wife-to-be. This was through the payment of two beasts, one for the motherin-law and one for the father-in-law. This is in line with the findings of Mawere and Mawere (2010:227), Gombe (2000:106) and Sibanda (1998:109) cited in Mangena and Ndlovu (2013:473-474).

However, the beasts were not to be dedicated to the ancestral sprits as this would be against the NBC of Zimbabwe's Christian doctrines of worshipping God through Jesus Christ.

Furthermore, we noted that the type of inculturation had to provide teachings that lobola had a biblical basis so that the Christian values are not lost in the process of inculturating the marriage rituals as shown by Genesis 34:12 and Exodus 22:17. The kind of inculturation had to safeguard the NBC of Zimbabwe's teaching that discourages the charging of exorbitant bride prices as the Shona and Ndebele questionnaire respondents noted that payment of bride price amongst the Shona people was too expensive and oppressive compared to the Ndebele people. This was supported by most of the observation and interview results. ${ }^{8}$ Therefore, the bride price arrangements were becoming more commercialised by numerous Shona people in these modern days.

To comment on this, we note that in African culture, lobola becomes oppressive when the girl's parents charge exorbitant amount of money and things, but if they ask symbolic amount and wedding it is wise; culture should not be illuminated because each people identify with their own culture.

As we also observed that there was controversy on the time to pay lobola and conduct of the marriage rituals, the debate outlined above concurs with what is propounded by some black women theologians. For instance, according to Landman (2000:185), Purity Malinga at a research meeting of the Faculty of Theology and Religion at Unisa declared that lobola is one of the reasons for violence against black women because it reduces women to the property of men. As such, the kind of inculturation should consider such controversial practices like the paying bride price and marrying in the sacred month of November. More so, the type of inculturation has to ensure that controversial rituals like the kusungira ritual of the Shona and Ndebele cultures that compromised the Christian doctrines are introduced with caution. We noted that the Shona believers practise the kusungira ritual, whilst the Ndebele believers use a different name when conducting such a ritual.

We established that the kind of inculturation had to preach and teach against the views that perpetuate the subordination and separation of females from males in a patriarchal society.

8. Mawere and Mawere $(2010: 226)$ declared that the father requests for a certain ( a mount of bride price [pfuma] called rugaba/rusambo which is meant to cover the heavy responsibility the parent underwent in raising the daughter. The groom is expected to pay a head of cattle (danga). Some are made to buy cell phones and cars as part of the bride price.
This actually subjugates women and deprives them of their self-worth. The positive images of women in Shona and Ndebele religions of the world were to be promoted. The traditional forms of the oppressive and one side-dominated approach, which arose from patriarchal religions, were to be discarded. We therefore concluded that the kind of inculturation that could facilitate greater engagement of commitment between the NBC of Zimbabwe and the Shona and Ndebele culture was quite diverse.

\section{Constraints to the inculturation of marriage rituals}

On the dimension of ecclesial scrutiny, pastors, elders, deacons and church committee members of a particular church in the NBC of Zimbabwe played a role in determining which Shona and Ndebele cultural practices could be incorporated in the church. The church leaders followed a congregational type of governance. The church leaders determined and outlined cultural practices that were biblical and that could be used in the NBC of Zimbabwe. The NBC of Zimbabwe members were not allowed to consult ancestral spirits to seek guidance and protection in the marriage rituals.

We concluded that some cultural practices like kusungira and ukucola rituals of Shona and Ndebele people were regarded as outdated by the respondents. Some were not incorporated because their origin and the value of retaining them were not known. Some like the veneration of ancestors could not be adopted because of clash of doctrines. Those that promoted the veneration of ancestral spirits were not in line with Christian doctrine of regarding Jesus Christ as the mediator between God and human. Some members of the NBC of Zimbabwe thought that inculturation of marriage rituals would make their prayer requests to God not to be achieved as they believed that God is for a pure Christian religion.

Another constraint was that there were many cultural and ethnic groups in the NBC of Zimbabwe apart from the Shona and Ndebele people. These included the Venda, Tonga, Sotho, Shangaan and Kalanga. Each tribe represented would need its own culture to be incorporated. Some of the Shona and Ndebele cultural practices were expensive and seemed oppressive. The danger of syncretism was raised as one of the obstacles to the incorporation of Shona and Ndebele cultural practices into the NBC of Zimbabwe marriage rituals. Therefore, that became a hindrance to the inculturation of marriage rituals.

Having delineated some of the constraints to the inculturation of marriage rituals in the NBC of Zimbabwe, in the next section we consider the inculturation of marriage rituals in line with Kritzinger's dimension of biblical tradition.

\section{Interpretation of the Bible vis-à-vis the marriage rituals}

On objective 4 concerning biblical tradition, we established that the leaders and members of the NBC of Zimbabwe 
interpreted the Bible vis-à-vis the marriage practices in line with what the constitution of the Convention regards as biblical. The leaders and members promoted payment of lobola because they believed that it was also practised in the Old Testament and New Testament. For instance, some of the interviewees pointed out that the payment of bride price is supported by a number of verses in the Bible. Some interviewees even cited Genesis 34:12 as supportive evidence when Shechem spoke to Jacob, Dinah's father and brothers saying that a price and gift for the bride should be made. In the New Testament, Jesus in the Gospel of John also attended the wedding at Cana. They accepted monogamy basing on the Convention's constitution and its biblical support. However, they did not support polygamy since it was not in line with the NBC of Zimbabwe constitution, although it was biblical. We have noted that some Holy men like Abraham, Jacob, Elkanah and many more were polygamists.

The interviewees did not support ancestor veneration, as it clashed with their doctrinal belief of worshipping God through Jesus Christ (Jn 14:6), where Jesus said, 'I am the way, the truth and the life. No one can come to the Father except through me'. Therefore, an appropriate spirituality for inculturating marriage practices should be one (McGrath 1999):

[W]hich arises from a creative and dynamic synthesis of faith and life, forged in the crucible of the desire to live out the Christian faith, authentically, responsibly, effectively, and fully. (p. 9)

In brief, we can say this type of spirituality is one that animates the NBC of Zimbabwe believer's life, which moves a person's faith to greater depths and perfection.

\section{Motivation for the inculturation of marriage rituals}

Regarding objective 5 on the dimension of discernment for action, most of the interview and observation results from churches A, B, C, D and E revealed that various reasons motivated the NBC of Zimbabwe to adopt some of the Shona and Ndebele cultural practices into their marriage rituals. Keeping cultures, winning believers to Christ and preventing disputes were some of the reasons why the NBC of Zimbabwe incorporated some of the Shona and Ndebele cultural practices into its marriage rituals. Some of the cultural practices were adopted because they were biblically commendable. The incorporation of these practices made the NBC of Zimbabwe members feel at home. Some were fused because of the desires of the parents.

For instance, most of the interview results we got confirmed this. For instance, at Church A in Midlands region in December 2017, we noted that some members of the NBC of Zimbabwe were married to unbelievers. In this case, the incorporation of their Shona and Ndebele cultural practices catered for their cultural beliefs. Some members, although Christians, still upheld their Shona and Ndebele cultural beliefs. Thus, the NBC of Zimbabwe identified with cultures and traditions of members as a way of attracting them to the church.

Even the interview results that we got in January 2017 at churches $\mathrm{E}$ and $\mathrm{F}$ confirmed this, which showed that the National Executive members, pastors, elders, deacons, church committee members and lay members were after winning believers to Christ. For instance, according to church committee member F4 (Interview 14, 23 January 2017) in Matabeleland region:

'As the NBC of Zimbabwe members, we accommodate some Shona and Ndebele marriage cultural practices so that the believers will be easily converted to Christ since we will be making use of their cultural practices. As such, they will not feel to be out of place when in the church. More so, this is done in fulfilment of the Great commission given by Jesus Christ.'

This has resulted in the increase of members in the NBC of Zimbabwe churches, as they found it difficult to limit people's rituals.

What we discovered above is in line with the findings of Soosamariam (2006:1) who notes that in the process of transmitting the Good News, evangelisation must purify culture. Therefore, cultural elements must be reflected. It is therefore prudent that in the inculturation of the Gospel message, its meanings and values must be declared to the hearers using their own cultural symbols and language to enable them to feel at home in their own culture and church people must be excited about sharing in the mission of the Universal Church, which refers to the church universal. The NBC of Zimbabwe has taken such an approach.

More so, the NBC of Zimbabwe had a concept similar to what was observed by Magesa (2004:10) in the Catholic Church in Kenya. The Catholic officials cited cultural awareness and pride on the one hand and Christianity's potential contribution to the growth of African culture on the other hand as one of the reasons for inculturation. Thus, the African Christians in Kenya would identify with the Christian church and treat it as their own, rather than as a foreign organisation through inculturation of their cultural practices. These were some of the driving forces for the inculturation of marriage rituals within the NBC of Zimbabwe in Midlands and Matabeleland regions.

\section{Shona and Ndebele cultural aspects adopted in the National Baptist Convention of Zimbabwe}

Regarding objective 6 on the dimension of reflexivity, we established that the NBC of Zimbabwe had been able to inculturate Shona and Ndebele marriage rituals although only into a limited extent because of numerous limiting factors. For instance, bride price payment was adopted as the respondents saw numerous benefits of having it. Moreover, the interviewees had perceived that this was in line with their Christian beliefs. For instance, in Genesis 29:16-28, Jacob had to work for 7 years for Rachel, which 
indicated a high level of commitment to the marriage. Although polygamy is biblical, it has not been adopted into the NBC of Zimbabwe. This was because it is against the constitution of the Convention.

At times, however, the adoption of certain Shona and Ndebele cultural rituals had a problem that some members of the NBC of Zimbabwe would end up observing some rituals secretly. This occurred because it was not possible for the pastors, elders and deacons to monitor each and every ritual observed. We observed that some Ndebele and Shona parents would dedicate the bride to ancestral spirits when she was going to the in-laws' home. When the bride reached the home of the groom, she would be committed to the ancestral spirits of the groom's family. Therefore, it was a bit difficult to monitor the veneration of ancestral spirits by the parents and relatives when a bride was married. The parents and the relatives of the bride and groom would do that in privacy as they knew that the NBC of Zimbabwe does not condone such rituals. Therefore, the pastors, elders, deacons and church committee members should continuously preach and teach against such activities in the Convention, as this is against the NBC of Zimbabwe's Christian doctrine.

Whilst the payment of lobola and conduct of marriage rituals could be incorporated into the NBC of Zimbabwe teachings, from most of the interviews and observation results we noted that controversies arose regarding these. Some of these controversies were about the times when the marriage rituals should be conducted. Whilst some asserted that one could marry and pay lobola any time of the year including November, others were strongly against such a position, which shows that this is a controversial matter in the NBC of Zimbabwe.

Furthermore, we also noted that the NBC of Zimbabwe adopted the Shona and Ndebele cultural aspects of marrying someone whose background is known. ${ }^{9}$ The NBC of Zimbabwe encouraged the members to marry or to be married to someone within the NBC of Zimbabwe, who was morally upright. The NBC of Zimbabwe members had done that so that their Christian doctrines would remain undiluted. However, from the findings we also established that some members of the NBC of Zimbabwe would marry people from other churches like the Apostolic Faith Mission in Zimbabwe, the Evangelical Lutheran Church in Zimbabwe, the Dutch Reformed Church in Zimbabwe and the Roman Catholic Church. Some believers even married nonChristians with the hope of ministering to such a person to become a convert. This group of congregants thought that they had powers to marry anyone they felt like marrying regardless of that person's cultural background and behaviour. $^{10}$

9.This group of believers followed a Shona proverb which says Rooreranai vamatong or Ndebele proverb which says Ukhuniolungaziwayokaluthezwa.

10.This other group of believers followed the Shona proverb, which says Moyo muti unomera paunoda or Ndebele proverb which says Umkhosi wenhliziyo
We found that the NBC of Zimbabwe even adopted the guidance and counselling of the Shona and Ndebele cultures. Whilst in the Shona and Ndebele cultures mostly the aunts and uncles did this, in the NBC of Zimbabwe elders, deacon and pastors mostly did this. The youth advisors would guide and counsel especially during the youth meetings and conferences. What the youth advisors, elders, deacons and pastors did complement the role of the aunts and uncles in the Shona and Ndebele cultures. Ululating, dancing and giving of gifts were some of the cultural practices that were incorporated into the NBC of Zimbabwe. This was quite evident when a bride was being sent to her in-laws' house for the first time. This practice is called kupereka muroora in Shona language, whilst in Ndebele this is called ukuphelekezela umalokhazana.

This was done during the conduct of the NBC of Zimbabwe wedding ceremonies when the members would be conducting rituals associated with such events.

\section{Benefits of inculturation of marriage rituals in the National Baptist Convention of Zimbabwe}

In terms of Kritzinger's dimension of reflexivity, we noted that the inculturation of marriage rituals had a number of possible benefits for the NBC of Zimbabwe members. For instance, this was done to win more believers to Christ as confirmed by most of the interview results. Another possible benefit was the building of long-lasting marriages within the Convention as well as having one combined wedding ceremony. Some cultural practices were adopted to cultivate good morals, which also created strong relationships. Such relationships were made through uniting families with strong ties as well as having strong relations between the families and the church. It would result in coming up with one combined wedding ceremony so that the bride, groom and family relatives would not incur the heavy burden of conducting two wedding ceremonies, namely, from the traditional customary side and the church's side. This is in line with Okonkwo (2010:1) who notes that inculturation is a way of bringing the two together to avoid duplication or multiplication of rituals. Therefore, a number of factors drove the NBC of Zimbabwe to adopt some of the Shona and Ndebele cultural practices into its marriage rituals.

\section{Perceptions on the inculturation of marriage rituals in the National Baptist Convention of Zimbabwe}

Regarding objective 7 on the dimension of spirituality, we concluded that the sample respondents had varied perceptions about the inculturation of marriage rituals in the NBC of Zimbabwe. The majority of interviewees in churches A, B, C, $\mathrm{D}, \mathrm{E}$ and $\mathrm{F}$ thought that the inculturation of marriage rituals should be encouraged. A minority of participants were opposed to this idea. Some members noted that some cultural practices preserved Ubuntu/unhu/vumunhu. For example, the initiation rituals played a significant role of guiding and

awuphalalelwa. 
counselling people. This also helped in that they reduced the rate of divorce in the church, community and the nation. Thus, they should be promoted because they were full of good morals and respect.

Moreover, those group of respondents who supported the idea of inculturation pointed out that the cultural practices would act as an evangelism tool to win people to Jesus Christ. However, we observed that this group of people also asserted that the practices that were associated with the veneration of ancestral spirits were not to be promoted as they were against the biblical principles. Some members even indicated that the inculturation of marriage rituals should not be done at all because some of the cultural practices were not biblical. For instance, some members could practise ancestor veneration as no one would be able to monitor such activities at homes. A green light to inculturation might therefore result in syncretism being practised in the NBC of Zimbabwe, and the essence of the Christian gospel could therefore be lost. Some thought that their Christian God might end up even failing to answer their prayers because the believers would be supporting the works of the devil.

The interview results from some churches showed that the NBC of Zimbabwe might end up losing its Christian flavour. So it would be difficult in the end to draw a line between Christianity and the Shona and Ndebele cultures, as the two would have been fused into each other. Some interviewees thought that this might cause conflicts because the NBC of Zimbabwe is made up of members from varied cultural backgrounds, including Sotho, Kalanga, Venda, Shangaan, Tonga and Chewa people, as well as Shona and Ndebele. Each tribe would therefore need to be represented in terms of marriage cultural rituals. This would then cause serious divisions and fights in the NBC of Zimbabwe. Each cultural group would want its own cultural rituals to be adopted into the inculturation of marriage rituals. Even the marriage officers would have a hard time to understand every marriage cultural practice to be used in the conduct of marriage rituals. This group was strongly against anything with Shona and Ndebele cultures in it. They thought that Shona and Ndebele cultural practices were demonic and satanic in nature. Some of these respondents noted that some of the cultural practices were expensive and oppressive. Thus, they thought that payment of lobola should be discouraged. This has promoted cohabitation and Living-in amongst the Shona and Ndebele cultures. Thus, the group did not buy the idea of encouraging the inculturation of marriage cultural rituals in the NBC of Zimbabwe. Therefore, the Convention is implored to continuously preach and teach against the charging of exorbitant bride price.

Our comment on the above view is that because of the different cultural backgrounds of these tribes the NBC of Zimbabwe should respect the culture of each people in offering the Gospel message. The NBC churches do not intend to abolish or destroy what is good and beautiful. Many cultural values purify and take into Christian worship certain elements of people's customs.

\section{Ethical consideration}

Permission was obtained from the National Executive Committee of the Convention and other responsible authorities to collect data from the pastors, elders, deacons, committee members and the lay members and participants. Consent was obtained and confidentiality, respect for participants and the sites for the research were maintained. Participants were not put at risk. This in line with what has been suggested by scholars like Moorhead \& Griffin (1995). Research procedures and methods were reported faithfully and honestly.

\section{Discussion of findings}

Because in this article we sought to give a missiological critique of the inculturation of marriage rituals in the NBC of Zimbabwe, the findings drawn from the article are as follows:

1. Inculturation of marriage rituals is significant to the NBC of Zimbabwe. It has roles of upholding cultural rituals, guidance and counselling, promoting unity between NBC of Zimbabwe and community, and is a basis for strong marriages. Through inculturation, the Convention members stop leading double lives, one in the African Indigenous Religion and culture and the other in the NBC of Zimbabwe. This is done because the NBC of Zimbabwe operates within a certain culture of people. The Shona and Ndebele cultures are part of the cultural environment within which the NBC of Zimbabwe operates. If they ever find that their cultures are not accommodated, they would consult witch doctors and diviners in private.

2. The NBC of Zimbabwe has to a certain extent inculturated some aspects of Shona and Ndebele cultures into its marriage rituals. It has inculturated payment of lobola, marrying a person with a cultural background known as well as incorporating guidance and counselling. Ululating, dancing and giving of gifts are some of the cultural practices adopted. However, the NBC of Zimbabwe has not inculturated ancestor veneration, expensive and oppressive cultural practices, polygamy and divination. Polygamy has not been inculturated although it is biblical, as some holy men like Abraham, David and Solomon were polygamists. Makaza (2013) and Chabata (2014) also note that the NBC of Zimbabwe constitution emphasizes on monogamy.

3. The inculturation of marriage rituals has become a challenge for the NBC of Zimbabwe in some ways. Some Baptists become Christians by daylight and yet become ancestor consultants by night. At times, they are not comfortable with the assistance offered by the NBC of Zimbabwe. Consequently, they often consult the ancestors and diviners under the cover of darkness in fear of other Christians and church authorities.

4. The inculturation of marriage rituals in the Convention has been hindered by numerous constraints. For instance, some of the Shona and Ndebele cultural practices have been regarded as not scriptural, outdated, expensive and oppressive. Also some members do not know the reasons 
why certain cultural practices like the kusungira ritual are observed. Some members of the NBC of Zimbabwe feared the danger of syncretism.

5. The NBC of Zimbabwe is composed of a number of different tribes like the Venda, Sotho, Kalanga, Tonga, Ndebele and Shona, who may want their cultural practices to be incorporated into the marriage rituals. Since the Convention is composed of members of different cultural backgrounds, it becomes a challenge to adopt the cultural marriage values of only the Shona and Ndebele people. Each group represented would then want to be catered for.

6. Parents or guardians of the bride are important in the inculturation of marriage rituals because the parents' consent is important during the conduct of any wedding ceremony. Along with this, the NBC of Zimbabwe expects members who have wedded through Shona and Ndebele traditional customary ways to wed again in the church.

7. The commercialised bride price has become a challenge for the NBC of Zimbabwe. The lobola arrangements are becoming more and more commercialised and are being increasingly abused. Charging exorbitant lobola has become an obstacle to canonical marriage because of the high price demanded by the bride's family. Purity Malinga, at a research meeting of the Faculty of Theology and Religion at Unisa, declared that lobola is one of the reasons for violence against black women. This is because it reduces women to the property of men (Landman 2000:185). Commenting on that, Kobo (2016) remarks that when Purity Malinga gave such a statement, the black men in the meeting accused her, saying she uses feminism to divide the black people into male and female. This shows that some black women theologians are against the payment of lobola. This makes the payment of lobola a controversial issue.

8. The traditional ritual of paying the bride price is significant in the inculturation of marriage rituals. According to Mangena and Ndlovu (2013:475), in traditional Ndebele marriage, before the children were born, the bride's father paid more than the groom's father did in the establishment of the new family. For example, he gave his daughter a beast to take to her new home. In this case, the beast is a sign to the groom's family that the bride is serious about marriage. This beast becomes the foundation of the home as it multiplies. The initiation rituals play a significant role of guiding and counselling the youths. Therefore, there is a need for them to be accepted. This also helps in that they reduce the rate of divorce in the church, community and the nation.

9. Some Shona and Ndebele cultural rituals compromise Christian doctrines. For instance, the Shona people conduct the kusungira ritual. The Ndebele believers also conduct such a ritual although under a different name. This allows the mother of the pregnant woman time to monitor her daughter during the last months of her pregnancy. The pregnant woman was guided and counselled on how to handle the newborn baby. However, according to the doctrinal beliefs of the NBC of Zimbabwe, during the conduct of such a ritual there should be no use of herbs by the mother to open the birth canal. There should be no smear of traditional medicine on the head (kurapa nhova) and the navel of the newborn baby to protect him or her. At times, some Shona and Ndebele believers would tie some charms around the waist and the neck of the baby as a form of protection. In Ndebele language, the charms are called intebe. This is strongly against the NBC of Zimbabwe's doctrine of believing in an Almighty God. The Convention should come up with polices that discourage the conduct of such activities in the Convention.

10. On perception regarding the promotion of the inculturation of marriage rituals in the NBC of Zimbabwe, we established that most of the interview and observation results have two varied positions. We observed that the majority of leaders and/or members believe that the inculturation of marriage rituals should be promoted in the church, whilst a few were saying that it should not be promoted at all.

Our point of view is that polygamy radically contradicts marriages of Christian unity. The negative elements in polygamous culture are discrimination against and oppression of women, disunity, untrue love, infidelity of a man, jealousy and marrying girls who are below the legal minimum age; thus, polygamy cannot be inculturated. There is a need to bring awareness to African people to be able to discern what reduces their self-esteem in the community.

\section{Recommendations}

Based on the research findings, we recommend following to expedite the inculturation of marriage rituals in the NBC of Zimbabwe to bring them into line with the Shona and Ndebele cultures:

1. Firstly, the National Executive Committee members, pastors, elders, deacons and church committee members of the NBC of Zimbabwe should encourage the payment of the bride price called roora in Shona language and lobola in Ndebele language. No one should be encouraged to marry in the NBC of Zimbabwe before paying part of or the whole bride price as demanded by the in-laws. Such a stance is in line with Genesis 34:12 and Exodus 22:17. Payment is an exhibition of love, which exhibits great commitment of the bride and groom to marriage. The attachment of a value to the woman is a way of according a status, which is commendable, even in the NBC of Zimbabwe's marriage rituals.

2. The NBC of Zimbabwe leaders should encourage the groom and relatives to appreciate the parents or guardians for bringing up the wife-to-be in the inculturation of marriage rituals. This is through the payment of two beasts: one for the mother-in-law and one for the father-in-law. However, the beasts are not to be dedicated to the ancestral spirits as this would be against the NBC of Zimbabwe's Christian doctrines of worshipping God through Jesus Christ. 
3. The commercialised bride price has become a challenge for the NBC of Zimbabwe. The lobola arrangements are becoming more and more commercialised and are being increasingly abused. Charging exorbitant lobola has become an obstacle to canonical marriage because of the high price demanded by the bride's family. Given such a scenario, in the inculturation of marriage rituals into the NBC of Zimbabwe, the bride's family are implored to know that when they charge exorbitant amounts of lobola they compromise the future of their daughter.

4. The NBC of Zimbabwe National Executive Committee members, pastors, elders, deacons and church committee members should also encourage the traditional ritual of paying the bride price because it is a noble idea. We noted that before the children were born, the bride's father paid more than the groom's father did in the establishment of the new family. For example, he gave his daughter a beast to take to her new home. In this case, the beast would be a sign to the groom's family that the bride is serious about marriage. This beast becomes the foundation of the home as it multiplies. As such, we recommend the NBC of Zimbabwe leaders to encourage such a noble idea. But in the case of urban families there might not have a place to keep cattle, and if the gift takes the form of cars and cell phones, it will not multiply but just depreciate in value. More so, if there is intermarriage between Shonas and Ndebeles, the Shonas may misinterpret the procedure accusing the bride and in-laws of being desperate for marriage. Suppose one beast in the herd of the groom's family dies unceremoniously, the family may suspect that their in-laws sent a curse through the bride's beast. In view of this, the National Executive Committee members, pastors, elders and deacons are implored to guide and counsel the Shona in-laws on the significance of such a procedure.

5. Shona and Ndebele initiation rituals play a significant role in guiding and counselling the youths. Therefore, there is a need for them to be accepted. This helps in that they reduce the rate of divorce in the church, community and the nation. Thus, they should be promoted because they are full of good morals and respect. However, this may not fit in some Zimbabwean homes where some people including the bride's aunts and groom's uncles may be living in the diaspora. Therefore, we recommend that the pastors, elders, deacons and youth leaders should help in initiating couples. The Convention leaders are implored to promote the Shona and Ndebele cultural practices that uphold good morals and respect in the inculturation of the marriage rituals. Such cultural practices preserve Ubuntu/unhu/ vumunhu. This can be done especially during church services, youth meetings and conferences. This can also be done during the conduct of bridal showers and bachelor's parties. What they would be doing strongly complements the role of the aunts and uncles in the Shona and Ndebele cultures. This in some way may reduce cultural conflicts within the NBC of Zimbabwe and produces an authentic African Christian church.
6. Some of the parents and relatives of the bride and groom practise veneration of ancestral spirits in privacy, as they are aware that the NBC of Zimbabwe does not condone such rituals. The NBC of Zimbabwe shuns ancestor veneration and consultation of diviners. It should make policies that adopt and promote all the cultural practices that are in line with the Christian doctrines. Anything against the Christian Bible should not be condoned without justification. This also preserves the Shona and Ndebele cultural practices. As such, there is a need for a conservative African theology to try to determine ways and means of accommodating such aspects of ancestor veneration.

7. Whilst some members asserted that one could marry and pay lobola any time of the year including November, others were strongly against this position, which shows that this is a controversial matter within the NBC of Zimbabwe and could be the cause of conflicts and divisions within the church. Therefore, the NBC of Zimbabwe is encouraged to strongly preach, teach and advise on such issues in relation to the inculturation of marriage rituals. The National Executive Committee, pastors, elders and deacons should craft a policy regarding such controversial issues.

8. The pastors, elders and deacons of the NBC of Zimbabwe are encouraged to uphold with caution practices of the Shona and Ndebele cultural rituals that compromise the Christian doctrines. For instance, the Shona people conduct the kusungira ritual. According to the doctrinal beliefs of the NBC of Zimbabwe, during the conduct of such a ritual, there should be no use of herbs by the mother to open the birth canal. Again, the NBC of Zimbabwe prohibits the application of traditional medicines as a way of protecting the newborn baby. The Convention believes in a God who is all-powerful, omniscient and omnipresent. The National Executive Committee should come up with policies that discourage the conduct of such activities in the Convention.

9. Because the NBC of Zimbabwe is composed of many cultural groups we recommend the Convention to inculturate good and biblical cultural practices as it is very important to accommodate everyone in his or her culture to feel at home. In addition, the National Executive Committee members, pastors, elders and deacons should learn and appreciate the marriage cultural practices of congregants within the shortest period. They should even engage services of people of that cultural extraction. Therefore, inculturation of marriage rituals should be open to everyone so that fears are removed from the members, as culture is dynamic and people are living in a global village. Above all, instead of being dogmatic the NBC of Zimbabwe should be able to cater for a multicultural set-up of the Venda, Sotho, Ndebele, Shona, Shangaan and Kalanga people. Its members should continue the upholding of adopted Shona and Ndebele cultural practices that are biblical and are in line with the constitution of the Convention.

10. The NBC of Zimbabwe leaders are implored to combine their church wedding ceremony with that of the Shona and 
Ndebele traditional types. This would enable the couple not to incur heavy costs of having two different ceremonies especially during hard times. Moreover, we urge the NBC of Zimbabwe elders and deacons to continue with their roles of accompanying a bride-to-be and groom-to-be to the in-laws whenever they are preparing for the marriage and church wedding ceremonies. This ensures that what is not biblical is not brought into the inculturation of marriage rituals, for example, virginity testing done by the Kalanga father-inlaws in the Matabeleland region. For instance, Dube (2013) and Dube (2014) point out that among the Kalanga of Zimbabwe the father-in-laws do virginity testing to the daughter- in-laws who join the family. Therefore, this is one of the emergency issues the faith community and scholars need to address in order to eliminate.

11. The NBC of Zimbabwe National Executive Committee members, pastors, elders and deacons are encouraged to preach and teach against views that perpetuate the subordination and separation of males from females in a patriarchal society. These actually subjugate women and deprive them of their self-worth. The positive images of women in Shona and Ndebele religions of the world should be promoted. Policies should be crafted to deal with such matters. The traditional forms of oppressive and one side-dominated approach which arise from patriarchal religions are to be discouraged.

12. Finally, we urge the NBC of Zimbabwe National Executive Committee members, pastors, elders, deacons and church committee members to craft polices that promote the inculturation of marriage rituals. This would make the members not to become Christians by daylight and yet become ancestor consultants by night.

\section{Conclusion}

In a nutshell, the majority of the respondents are of the opinion that the inculturation of marriage rituals has been in existence in the NBC of Zimbabwe since the time they became members. A number of marriage practices have been adopted because they play a number of significant roles in the NBC of Zimbabwe like bringing unbelievers to the Convention as well as keeping cultures. More so, they have numerous other benefits in the NBC of Zimbabwe. The inculturation of marriage rituals has been hindered by constraints like the fear of syncretism, not knowing their values and also the fact that the NBC of Zimbabwe is composed of many ethnic tribes like the Kalanga, Venda, Sotho, Venda and Tonga besides the Shona and Ndebele tribes. Despite all this the majority of the respondents thought that the inculturation of marriage rituals should be promoted in the NBC of Zimbabwe.

In summary, inculturation of marriage rituals in the NBC of Zimbabwe should be inclusive for the Shona and Ndebele people, not to benefit a few numbers of people. It should be an expression of the community life which can contribute to mature people within the community itself. Above all, inculturation needs to be guided and encouraged but not to be forced because it may raise negative reactions amongst Christians in the NBC of Zimbabwe.

\section{Acknowledgements Competing interests}

The authors have declared that no competing interest exist.

\section{Author(s) contributions}

All authors contributed equally to this work.

\section{Funding information}

The University of South Africa funded this research.

\section{Data availability statement}

Data sharing is not applicable to this article as no new data were created or analyzed in this study.

\section{Disclaimer}

The views and opinions expressed in this article are those of the authors and do not necessarily reflect the official.

\section{References}

Amadi, A.I., 2002, 'Inculturation in African churches with particular reference to Zimbabwe', Unpublished MTH thesis, University of South Africa.

Andifasi, J., 1970, 'An analysis of Roora', in C. Kileff \& P. Kileff (eds.), Shona Customs: Essays by African Writers, pp. 28-32, Mambo Press, Gweru.

Anthony, K., 2012, 'Inculturation and the Christian faith in Africa', International Journal of Humanities and Social Sciences 2(17), 236-244.

Banda, Z., 2010, 'African renaissance and missiology: A perspective from mission praxis', Unpublished DTh. thesis, Unisa.

Baron, E., Mangayi, L. \& Nel, R.W., 2017, The dynamics of mission, Only study guide of Module MIN1501, discipline of missiology, Unisa, Pretoria.

Bozongwana, W. Rev 2000, Ndebele Religion and Customs, Mambo Press, Gweru.

Chabata, N.R., 2014, National Baptist convention history, Unpublished.

Cohen, L. \& Manion, L, 1994, Research Methods in Education, 4th edn., Routledge, London.

Creswell, J.W., 2010, Qualitative research design: Choosing among five approaches, Sage, London.

Creswell, J.W. \& Plano Clark, V.L., 2011, Designing and conducting mixed methods research, 2 nd edn., University of Nebraska, Sage, London.

Dube, M., 2013, 'Kalanga do away with the marriage practice', The Standard, 28 July. Dube, M., 2014, 'Debunking the myths of Kalanga culture', Chronicle, 09 July.

Gombe, J.M., 2000, Tsika dzaVaShona. Rakavandudzwa, 2nd edn., College Press, Harare.

Gundani, P., 2000, 'Christology in the inculturated Shona burial in the Roman Catholic Church in Zimbabwe', in K. Fiedler, P. Gundani \& H. Mijonga (eds.), Theology cooked in the African pot, pp. 81-92, ATISTICA, Zomba.

Hatendi R.P. Rev, 1973, 'Shona Marriages and the Christian Churches' in A.J. Dachs (ed.), Christianity South of the Zambezi, Mambo Press, Gweru.

Johnson, B.R. \& Christensen, L.B., 2008, Educational research: Quantitative, qualitative and mixed approaches, 3rd edn., Sage, London.

Johnson, B.R. \& Christensen, L.B., 2010, Educational research: Quantitative, qualitative and mixed approaches, Sage, Los Angeles, CA.

Kobo, F., 2016, 'Umfazi akangeni ebuhlati emuzini - A womanist dialogue with black theology of liberation in the 21st century', HTS Teologiese Studies/Theological Studies 72(1), a3268. https://doi.org/10.4102/hts.V72il.36

Kritzinger, J.N.J., 2010, Integrated theological praxis: Capstone module the only study guide for BTH3720, Unisa, Pretoria.

Kurgat, S.G., 2009, 'The theology of inculturation and the African Church', International Journal of Sociology and Anthropology 1(5), 089-098.

Landman, C., 2000, 'Women using culture against women', in J. Marlherbe et al. (eds.), Women, society and constraints - A collection of contemporary South African gender studies, pp. 177-189, Unisa, Pretoria.

Leedy, P.D.J., 1993, Practical research, planning and design, Macmillan, London.

Leedy, P.D.J. \& Omrod, J.E., 2010, Practical research: Planning and design, Pearson Educational International, Boston, MA.

Magesa, L., 2004, Anatomy of inculturation: Transforming the church in Africa, Orbis, Maryknoll, NY. 
Makaza, T.C., 2013, 'The history of the NBC of Zimbabwe', A term paper presented, Theological College of Zimbabwe, Bulawayo, Unpublished.

Mangena, T. \& Ndlovu, S., 2013, 'Implications and complications of bride price payment on the Shona and Ndebele of Zimbabwe', International Journal of Asian Science 3(2), 472-481.

Manyoba, C.B., 1991, 'Methodist Church and its response to culture', in C.S. Banan (ed.), A century of methodism in Zimbabwe 1891-1991, The Methodist Church in Zimbabwe, Harare.

Mawere, M. \& Mawere, A.M., 2010, 'The changing philosophy of African marriage. The relevance of the Shona customary practice of kukumbira', Journal of African Studies and Development 2(9), 224-233.

McGrath, A.E.,1999, Science and Religion: An Introduction.

Mertens, D., 2005, Research and Evaluation in Education and Psychology: Interpreting Diversity with Quantitative, Qualitative and Mixed Methods, 2nd end., Boston, Sage.

Moorhead, G. \& Griffin, R.W., 1995, Organizational behavior: Managing people and organisations, 4th edn., Houghton Mifflin, Boston, MA.

MTHMS15, 2010, Structured MTh. Programme tutorial letter 101/2010. Discipline of missiology, Unisa, Pretoria.

Mwandayi, C., 2011, Death and after life rituals in eyes of the Shona: Dialogue with the Shona customs in the quest for authentic inculturation, vol. 6. of Bible in Africa studies, University of Bamberg Press.
Niebuhr, R.H., 2001, Christ and culture, Expanded edn., 15th edn., Harper One, Harper Collins Publishers.

Nyathi, P., 2001, Traditional ceremonies of the AmaNdebele, Mambo, Gweru.

Okonkwo, E., 2010, Concrete steps towards the inculturation of Christian sacramental and Igbo traditional marriage, European University Studies, p. 762

Phellas, C.N., Bloch, A. \& Seale, C., 2011, Structured methods: Interviews, questionnaire and observations, viewed 15 June 2014, from www.sageBCom/upm-data/ 47370 seal.

Political Map of Zimbabwe showing regions, viewed 30 April 2016, from www.google. com/search.

Shoko, T., 2009, 'Komba girls initiation rites and inculturation among the Varemba of Zimbabwe', Studia Historiae Ecclesiasicae 35(1), 31-35.

Soosamariam, S., 2006, 'Attempts at inculturation in the Malaysian church', E.A.P.R East Asian Pastoral Review 43(4)

Sunday News Online, 2016, 'The curse of November marriages', The Sunday News, viewed 27 November 2016, from http://www.sundaynews.co.zw/the-curse-ofnovember-marriages.

Thorpe, S.A., 1996, African traditional religions: An introduction, University of South Africa, Pretoria. 